\title{
HUBUNGAN KERAPATAN RUMPUT LAUT DENGAN SUBSTRAT DASAR BERBEDA DI PERAIRAN PANTAI BANDENGAN, JEPARA
}

\author{
Nur Ain, Ruswahyuni ${ }^{1}$, Niniek Widyorini \\ Program Studi Manajemen Sumberdaya Perairan, Jurusan Perikanan, Fakultas Perikanan dan Ilmu Kelautan, \\ Universitas Diponegoro. J1. Prof. Soedarto, SH Tembalang- Semarang
}

\begin{abstract}
ABSTRAK
Pantai Bandengan adalah salah satu pantai pesisir utara Jawa yang terletak di Kabupaten Jepara, Jawa Tengah. Kabupaten Jepara memiliki potensi sumberdaya pesisir yang besar ditinjau dari keberadaan garis pantainya lebih dari $72 \mathrm{Km}$. Pantai Bandengan ini juga sebagai habitat rumput lautyang merupakan tumbuhan laut dasar perairan (fitobentos), makroalga, dan termasuk Thallophyta. Rumput laut tergolong tanaman yang hidupnya melekat pada substrat, seperti karang, lumpur, pasir, batu, dan benda keras lainnya atau bahkan melekat pada tumbuhan lain secara epifitik.

Penelitian ini bertujuan mengetahui hubungan kerapatan rumput laut dengan substrat dasar berbeda di perairan Pantai Bandengan. Metode yang digunakan dalam penelitian ini deskriptif menggunakan line transek sepanjang 100 meter dan kuadran transek 1x1 meter dengan tiga kali pengambilan. Setiap kuadran transek dilakukan pengukuran parameter fisika dan kimia meliputi kedalaman, kecerahan, kecepatan arus, suhu air, dan $\mathrm{pH}$ (untuk mendukung hasil data sampling).

Hasil yang didapatkan pada penelitian ini adalah sembilan jenis rumput laut yaitu Halimeda opuntia; Halimeda descoides; Halimeda macroloba; Chordoria flagelliformis; Padina crassa; Sargassum yendoi; Sargassum piluliferum; Sargassum confusum; dan Sargassum duplicatum. Kerapatan tertinggi ditemukan pada Halimeda opuntia $(18,19 \%)$ atau total 103 individu dengan penutupan substrat $\left(12,54 \mathrm{~m}^{2}\right.$, terbanyak pada substrat pecahan karang). Sedangkan penutupan tertinggi terdapat pada jenis Sargassum duplicatum yaitu $15 \mathrm{~m}^{2}$. Berdasarkan hasil analisa data Chi Kuadrat didapatkan nilai $\mathrm{X}^{2}$ hitung sebesar 72,00 dan nilai $\mathrm{X}^{2}$ tabel sebesar 21,026. Hal tersebut dapat dinyatakan ada hubungan kerapatan rumput laut terhadap substrat dasar karena $\mathrm{X}^{2}$ hitung $\geq \mathrm{X}^{2}$ tabel yang menyatakan terima $\mathrm{H}_{1}$ tolak $\mathrm{H}_{0}$.
\end{abstract}

Kata kunci: Rumput Laut, Kerapatan, Substrat Dasar, Pantai

\section{ABSTRACT}

Bandengan beach is one of the northern Java coastal, which is located in Jepara, Central Java. Jepara Regency has great potential for coastal resources in terms of its coastline more than $72 \mathrm{~km}$. The beach is also habitat of seaweed, that is a bottom sea plant (phytobenthos), macroalgae, and included Thallophyta. Seaweed is water plant that life attach to coral, mud, sand, rock, dan another hard objects and even to another plant as ephyfit.

This research aims to determine relationship of seaweed density with different substrate in Bandengan beach. This research uses descriptive method with line transects and quadrants transects along 100 meter with three repetitions. On each quadrant transect, physical and chemical parameter including depth, water transparency, water current, water temperature, and $\mathrm{pH}$ were measured to support this research.

The results found nine species of seaweed that are Halimeda Opuntia; Halimeda descoides; Halimeda macroloba, Chordoria flagelliformis; Padina crassa, Sargassum yendoi; Sargassum piluliferum; Sargassum confusum; and Sargassum duplicatum. The Highest density found is Halimeda Opuntia (18.19\%) or a total of 103 individuals with the substrat canopy of $12,54 \mathrm{~m}^{2}$ (mostly in rubble substrate). Whereas the highest canopy is Sargassum duplicatum $\left(15,00 \mathrm{~m}^{2}\right)$. Based on the Chi Square analysis, the $\mathrm{X}^{2}$ counted value is 72,00 and $X^{2}$ table value is 21,026 . It can be stated that there is a relation between sea weeds density to bottom substrate since $\mathrm{X}^{2}$ counted $\geq \mathrm{X}^{2}$ tables, which means accepts $\mathrm{H}_{1}$ and reject $\mathrm{H}_{0}$

Keywords: Seaweeds, Density, Bottom Substrate, Coastal

*) Penulis Penanggung Jawab 


\section{A. PENDahuluan}

Pantai Bandengan adalah pantai pesisir utara Jawa yang terletak di Kabupaten Jepara, Jawa Tengah. Kabupaten Jepara memiliki potensi sumberdaya pesisir yang besar ditinjau dari keberadaan garis pantainya lebih dari $72 \mathrm{Km}$. Pantai Bandengan merupakan daerah teluk berpasir putih yang tidak memiliki ombak terlalu besar sehingga dijadikan sebagai kawasan wisata unggulan Jepara. Pantai ini juga sebagai habitat rumput laut, dimana pada musim tertentu rumput laut sangat banyak tumbuh di kawasan ini.

Rumput laut merupakan sumberdaya hayati yang sangat melimpah di Indonesia. Terdapat sekitar 782 jenis rumput laut yang ditemukan hidup di perairan Indonesia. Bila dibagi berdasarkan pigmennya, jenisjenis tersebut terdiri dari 196 alga hijau, 134 alga coklat, dan 452 alga merah. Jenis-jenis tersebut tersebar di beberapa wilayah perairan Indonesia seperti Kepulauan Spermonde, Sulawesi Selatan, Sulawesi Tenggara, Sulawesi Tengah, Pulau Bali, Pulau Sumbawa, Pulau Sumba, dan perairan Maluku (Anggadireja dkk, 2009).

Rumput laut merupakan tumbuhan air yang tumbuh pada substrat dasar tertentu sesuai dengan intensitas sinar matahari yang masuk ke dalam perairan tersebut serta pergerakan arus untuk mempengaruhi persebarannya. Perbedaan substrat dasar pada perairan akan mempengaruhi kerapatan rumput laut. Hal ini juga ditinjau dari kondisi perairan yang dapat dilihat dari parameter fisika maupun kimianya. Pentingnya pengkajian mengenai pengaruh substrat dasar perairan terhadap tingkat kerapatan rumput laut ini nantinya diharapkan dapat mengetahui sejauh mana pengaruhnya dan jenis substrat apa yang paling potensial untuk pertumbuhan rumput laut di Pantai Bandengan.

Tujuan penelitian ini adalah untuk megetahui hubungan substrat dasar perairan dengan kerapatan rumput laut di perairan Pantai Bandengan. Penelitian ini dilaksanakan pada bulan Maret - April 2013 di perairan Pantai Bandengan, Jepara, Jawa Tengah.

\section{B. MATERI DAN METODE PENELITIAN \\ 1. Materi Penelitian}

Materi yang digunakan dalam penelitian ini adalah rumput laut yang tumbuh liar di perairan Pantai Bandengan dengan berbagai substrat berbeda. Alat yang digunakan disesuaikan dengan metode yang dipakai yaitu metode line transek dan kuadran transek. Alat tersebut adalah Global Positioning System (GPS), line transek 100 meter, kuadran transek 1x1 meter, refraktometer, termometer, pH universal, sabak, secchi disc, plastik sampel, label, underwater camera, masker snorkle, alat tulis, dan buku identifikasi rumput laut.

\section{Metode Penelitian}

Metode yang digunakan dalam penelitian ini adalah metode survei dimana metode ini bersifat deskriptif. Metode deskriptif adalah metode penelitian yang diadakan untuk memperoleh fakta-fakta dari gejala-gejala yang ada dan mencari keterangan secara faktual dari suatu kelompok ataupun suatu daerah kemudian melakukan analisa lebih lanjut mengenai kebenaran tersebut (Sandjaya, 2006). Metode ini bertujuan untuk membuat gambaran suatu keadaan secara objektif.

\section{Sampling dan Pengumpulan Data}

Penentuan untuk lokasi sampling menggunakan metode observasi. Pada pengambilan data kerapatan rumput laut dan penutupannya menggunakan metode kuadran transek (besi) 1x1 meter yang diletakkan sepanjang line 100 meter dari bibir pantai. Pengamatan ini menggunakan ulangan tiga kali pada setiap titik samplingnya.

Tahapan dari sampling rumput laut adalah observasi lapangan untuk menentukan titik sampling, plotting GPS, pemasangan line transek dan kuadran transek 1x1 meter, pengamatan dan pengambilan data kerapatan dan penutupan rumput laut di dalam kuadran transek serta data parameter perairannya. Sampel rumput laut yang ditemukan kemudian diamati dengan kaca pembesar untuk melihat bentuk thallus dan air bladder-nya. Sampel ini kemudian diidentifikasi.

\section{Pengolahan Data}

Analisa perhitungan menggunakan rumus dalam Odum (1993), yaitu :

\section{a. Kerapatan relatif jenis rumput laut (KR)}

Metode ini dilakukan dengan cara mencatat seluruh jenis rumput laut dan menghitung kerapatan relatif dengan rumus sebagai berikut:

$$
\mathrm{KR}=\frac{\text { Jumlah individu jenis A }}{\text { Jumlah individu seluruh jenis }} \times 100 \%
$$

\section{b. Penutupan relatif jenis rumput laut $(\mathbf{P R})$}

Metode ini dilakukan dengan cara mengukur luas dasar yang tertutup rumput laut dengan cara mengukur luas koloni atau individu dalam $\mathrm{cm}^{2}$ yang kemudian dinyatakan dalam prosen penutupan relatif masing-masing spesies per meter persegi dengan rumus:

$\mathrm{PR}=\frac{\text { Penutupan individu jenis A }}{\text { Jumlah penutupan seluruh jenis }} \times 100 \%$ 


\section{c. Frekuensi penyebaran rumput laut}

Metode ini dilakukan dengan cara menghitung berapa kali kehadiran jenis tertentu kedalam sebuah plot dalam suatu komunitas kemudian menyatakan dalam prosen. Frekuensi relatif tiap jenis dalam suatu komunitas per meter persegi dihitung menggunakan rumus:

$\mathrm{FR}=\frac{\text { Frekuensi jenis A }}{\text { Frekuensi seluruh jenis }} \times 100 \%$

d. Nilai Penting, Indeks Kesamaan, dan Indeks Ketidaksamaan

Setelah nilai KR, PR, dan FR, maka dilanjutkan dengan menghitung beberapa nilai berikut: $\mathrm{NP}=\mathrm{KR}+\mathrm{PR}+\mathrm{FR}$

Keterangan: $\quad$ KR : Kerapatan jenis rumput laut

PR : Penutupan jenis rumput laut

FR : Frekuensi penyebaran rumput laut

NP : Nilai penting

IK dapat dihitung dengan rumus:

$$
\begin{aligned}
\mathrm{IK} & =\frac{2 W}{a b} \times 100 \% \\
\mathrm{ITS} & =100 \%-\mathrm{IK}
\end{aligned}
$$

$\begin{array}{lll}\text { Keterangan: } & \text { a } & \text { : Jumlah NP seluruh jenis dalam komunitas a } \\ & \mathrm{B} & \text { : Jumlah NP seluruh jenis dalam komunitas b } \\ & 2 \mathrm{~W} & \text { : Jumlah NP terkecil dari seluruh jenis dalam komunitas a dan } \mathrm{b} .\end{array}$

Matrik IK/ITS

\begin{tabular}{|c|c|c|c|c|c|}
\hline ITS & $\begin{array}{c}\text { KH } \\
\text { (Karang Hidup) }\end{array}$ & $\begin{array}{c}\text { KM } \\
\text { (Karang Mati) }\end{array}$ & $\begin{array}{c}\text { PK } \\
\text { (Pecahan Karang) }\end{array}$ & $\begin{array}{c}\text { P } \\
\text { (Pasir) }\end{array}$ & Jumlah \\
\hline $\begin{array}{c}\text { KH } \\
\text { KM } \\
\text { (Karang Mati) }\end{array}$ & & & & & \\
\hline $\begin{array}{c}\text { PK } \\
\text { (Pecahan Karang) }\end{array}$ & & & & & \\
\hline $\begin{array}{c}\text { P } \\
\text { Pasir) }\end{array}$ & & & & & \\
\hline
\end{tabular}

Gambar 1. Matriks IK dan ITS

\section{e. Hipotesis Penelitian dan Uji Chi Kuadrat $\left(\mathbf{X}^{\mathbf{2}}\right)$}

Penelitian ini dilakukan untuk menduga adanya hubungan kerapatan rumput laut dengan substrat dasar pada perairan Pantai Bandengan. Hipotesis yang diambil adalah sebagai berikut:

$\mathrm{H}_{0}=$ Diduga terdapat hubungan antara kerapatan rumput laut dengan substrat dasar di Pantai Bandengan

$\mathrm{H}_{1}=$ Diduga tidak terdapat hubungan antara kerapatan rumput laut dengan substrat dasar di Pantai

Bandengan

Kaidah pengambilan keputusannya adalah sebagai berikut :

Jika $\mathrm{X}^{2}$ hitung $>\mathrm{X}^{2}$ tabel maka $\mathrm{H}_{0}$ ditolak dan $\mathrm{H}_{1}$ diterima

Jika $\mathrm{X}^{2}$ hitung $<\mathrm{X}^{2}$ tabel maka $\mathrm{H}_{0}$ diterima dan $\mathrm{H}_{1}$ ditolak

Uji Chi Kuadrat merupakan uji yang dipakai untuk mengetahui interaksi dua variabel yaitu variabel bebas tutupan substrat dasar dengan variabel terikat kerapatan dari rumput laut (Sudjana, 2005). Pengujian ini menggunkan bantuan program SPSS untuk mendapatkan validasi data.

\section{HASIL DAN PEMBAHASAN}

1. Hasil

a. Gambaran umum lokasi penelitian

Lokasi penelitian ini dilaksananakan di Pantai Bandengan, Kabupaten Jepara yang terletak pada $26^{\circ}$ 37' 53,94" LS dan $110^{\circ} 38^{\prime} 17,80^{\prime}$ " BT. Pantai ini terletak di sebelah utara kota Jepara yang berjarak $8 \mathrm{~km}$ dari pusat kota. Jepara merupakan wilayah timur pantura Jawa Tengah, dimana sebelah barat dan timurnya berbatasan dengan laut sedangkan wilayah timurnya adalah daerah pegunungan. 


\section{b. Jenis rumput laut}

Rumput laut yang ditemukan pada penelitian ini adalah 9 jenis, yaitu Halimeda opuntia, Halimeda descoides, Halimeda makroloba, Padina crassa, Chordoria flagelliformis, Sargassum yendoi, Sargassum piluliferum, Sargassum duplicatum, dan Sargassum confusum, yang dapat dilihat pada Tabel 2 berikut.

Tabel 1. Jenis Rumput Laut yang ditemukan di Perairan Bandengan (+ : ditemukan, - : tidak ditemukan)

\begin{tabular}{clcccc}
\hline No. & \multicolumn{1}{c}{ Jenis } & KH & KM & PK & P \\
\hline 1. & Halimeda macroloba & - & - & + & + \\
2. & Halimeda opuntia & - & + & + & + \\
3. & Halimeda descoides & - & + & + & + \\
4. & Chordoria flagelliformis & - & - & + & + \\
5. & Padina crassa & + & + & + & + \\
6. & Sargassum yendoi & - & + & + & + \\
7. & Sargassum confusum & + & + & + & + \\
8. & Sargassum piluliferum & - & + & + & + \\
9. & Sargassum duplicatum & + & + & + & + \\
\hline \multicolumn{7}{l}{ Total Spesies } & 3 & 7 & 9 & 9 \\
\hline
\end{tabular}

Sumber: Data penelitian 2013

$\begin{array}{lllll}\text { Keterangan: } & \text { KH } & \text { : Karang Hidup } & \text { KM } & \text { : Karang Mati } \\ & \text { PK } & \text { : Pecahan Karang } & \text { P } & \text { : Pasir }\end{array}$

Berdasarkan Tabel 2, pada substrat karang hidup ditemukan 3 jenis rumput laut dan pada substrat karang mati ditemukan 7 jenis. Rumput laut banyak menempel pada substrat dasar pecahan karang dan pasir.

c. Perhitungan nilai penting rumput laut di Pantai Bandengan

Berikut adalah data kerapatan, penutupan, frekuensi, serta nilai penting substrat rumput laut di Pantai Bandengan.

Tabel 2. KR, PR, FR, dan NP rumput laut di Pantai Bandengan (individu/300 $\mathrm{m}^{2}$ )

\begin{tabular}{|c|c|c|c|c|c|c|c|c|c|}
\hline No. & Filum & Spesies & $\begin{array}{c}\mathrm{K} \\
\text { (indv) }\end{array}$ & $\begin{array}{l}\mathrm{KR} \\
(\%)\end{array}$ & $\begin{array}{c}\mathrm{P} \\
\left(\mathrm{m}^{2}\right)\end{array}$ & $\begin{array}{l}\text { PR } \\
(\%)\end{array}$ & $\mathrm{F}$ & $\begin{array}{l}\text { FR } \\
(\%)\end{array}$ & NP \\
\hline 1. & Chlorophyta & Halimeda macroloba & 84 & 14,84 & 10,83 & 11,507 & 29 & 14,2157 & 40,56 \\
\hline 2. & & Halimeda opuntia & 103 & 18,19 & 12,54 & 13,324 & 37 & 18,1373 & 49,66 \\
\hline 3. & & Halimeda descoides & 98 & 17,31 & 10,29 & 10,934 & 33 & 16,1765 & 44,45 \\
\hline 4. & Phaeophyta & Chordoria flagelliformis & 45 & 7,95 & 4,90 & 5,206 & 18 & 8,82353 & 21,98 \\
\hline 5. & & Padina crassa & 76 & 13,42 & 7,55 & 8,022 & 29 & 14,2157 & 35,66 \\
\hline 6. & & Sargassum yendoi & 33 & 5,83 & 9,90 & 10,519 & 14 & 6,86275 & 23,21 \\
\hline 7. & & Sargassum piluliferum & 30 & 5,30 & 9,00 & 9,563 & 9 & 4,41176 & 19,27 \\
\hline 8. & & Sargassum confusum & 47 & 8,30 & 14,10 & 14,982 & 16 & 7,84314 & 31,12 \\
\hline \multirow[t]{2}{*}{9.} & & Sargassum duplicatum & 50 & 8,83 & 15,00 & 15,939 & 19 & 9,31373 & 34,08 \\
\hline & & Total & 566 & & 94,11 & & 204 & & 300 \\
\hline
\end{tabular}

Sumber: Data penelitian 2013

Berdasarkan perhitungan diatas maka Halimeda opuntia merupakan spesies dengan nilai kerapatan relatif dan frekuensi relatif tertinggi.

Tabel 3. Jumlah Rumput Laut pada Substrat Dasar Perairan (individu/300 m²)

\begin{tabular}{clccccc}
\hline No. & \multicolumn{1}{c}{ Jenis } & KH & KM & PK & P & Total \\
\hline 1. & Halimeda macroloba & 0 & 0 & 43 & 41 & 84 \\
2. & Halimeda opuntia & 0 & 3 & 78 & 22 & 103 \\
3. & Halimeda descoides & 0 & 5 & 69 & 24 & 98 \\
4. & Chordoria flagelliformis & 0 & 0 & 33 & 12 & 45 \\
5. & Padina crassa & 10 & 15 & 28 & 23 & 76 \\
6. & Sargassum yendoi & 0 & 14 & 15 & 4 & 33 \\
7. & Sargassum confusum & 5 & 26 & 15 & 1 & 47 \\
8. & Sargassum piluliferum & 0 & 13 & 14 & 3 & 30 \\
9. & Sargassum duplicatum & 5 & 22 & 19 & 4 & 50 \\
\hline & Total Spesies & 20 & 98 & 314 & 134 & 566 \\
\hline
\end{tabular}

Tabel ini merupakan penjabaran jumlah rumput laut yang ditemukan pada masing-masing substrat dasar. Sebanyak 20 rumput laut ditemukan pada substrat karang hidup. Sedangkan rumput laut yang hidup di karang mati sebanyak 98. Pecahan karang merupakan substrat dengan temuan terbanyak yaitu 314, dan substrat pasir sebanyak 134 rumput laut. 
Tabel 4. Penutupan rumput laut terhadap substrat dasar perairan $\left(\mathrm{m}^{2}\right)$

\begin{tabular}{rlccccc}
\hline No. Jenis & \multicolumn{1}{c}{ KH } & KM & PK & P & Total \\
\hline 1. Halimeda macroloba & 0 & 0 & 5,55 & 5,28 & 10,83 \\
2. Halimeda opuntia & 0 & 0,40 & 9,45 & 2,69 & 12,54 \\
3. Halimeda descoides & 0 & 0,45 & 7,33 & 2,51 & 10,29 \\
4. & Chordoria flagelliformis & 0 & 0 & 3,55 & 1,35 & 4,90 \\
5. Padina crassa & 1,00 & 1,40 & 2,80 & 2,35 & 7,55 \\
6. Sargassum yendoi & 0 & 4,35 & 4,50 & 1,05 & 9,90 \\
7. Sargassum confusum & 1,40 & 7,60 & 4,71 & 0,39 & 14,10 \\
8. Sargassum piluliferum & 0 & 4,00 & 4,30 & 0,70 & 9,00 \\
9. Sargassum duplicatum & 1,45 & 6,90 & 5,50 & 1,15 & 15,00 \\
\hline
\end{tabular}

Sumber: Data penelitian 2013

Berdasarkan Tabel penutupan substrat tersebut dapat diketahui penutupan tertinggi adalah jenis rumput laut Sargassum duplicatum dimana jenis ini menutupi $15 \mathrm{~m}^{2}$. Sedangkan untuk jenis rumput laut yang paling sedikit penutupannya adalah jenis Chordoria flagelliformis yaitu menutupi hanya $4,90 \mathrm{~m}^{2}$. Berikut merupakan histogram dari penutupan rumput laut terhadap substrat dasar perairan. Histogram ini mempermudah pembacaan Tabel 4 dimana penutupan tertingginya terdapat pada substrat pecahan karang yang ditunjukkan dengan warna abu-abu.

Tabel 5. Frekuensi rumput laut pada substrat dasar (individu/300 $\mathrm{m}^{2}$ )

\begin{tabular}{clcccc}
\hline No. & \multicolumn{1}{c}{ Jenis } & KH & KM & PK & P \\
\hline 1. & Halimeda macroloba & 0 & 0 & 15 & 14 \\
2. & Halimeda opuntia & 0 & 2 & 23 & 12 \\
3. & Halimeda descoides & 0 & 2 & 22 & 9 \\
4. & Chordoria flagelliformis & 0 & 0 & 10 & 8 \\
5. & Padina crassa & 4 & 5 & 10 & 10 \\
6. & Sargassum yendoi & 0 & 6 & 7 & 1 \\
7. & Sargassum confusum & 2 & 7 & 6 & 1 \\
8. & Sargassum piluliferum & 0 & 4 & 4 & 1 \\
9. & Sargassum duplicatum & 3 & 9 & 5 & 2 \\
\hline & Total & 9 & 35 & 102 & 58 \\
\hline
\end{tabular}

Sumber: Data penelitian 2013

Berdasarkan hasil Tabel diatas maka dapat diketahui bahwa frekuensi kemunculan terbanyak pada substrat pecahan karang dan pasir. Hal ini dikarenakan kemunculan rumput laut lebih banyak pada dua substrat tersebut dibandingkan pada substrat karang hidup dan karang mati.

d. Nilai Indeks Kesamaan dan Indeks Ketidaksamaan pada rumput laut

Indeks Kesamaan (IK) dan Indeks Ketidaksamaan (ITS) dapat dilihat dalam matriks berikut ini:

\begin{tabular}{|c|r|r|r|r|r|}
\hline IK & $\begin{array}{c}\text { KH } \\
\text { (karang hidup) }\end{array}$ & $\begin{array}{c}\text { KM } \\
\text { (karang mati) }\end{array}$ & $\begin{array}{c}\text { PK } \\
\text { (pecahan karang) }\end{array}$ & $\begin{array}{c}\text { P } \\
\text { (pasir) }\end{array}$ & Jumlah \\
\hline $\begin{array}{c}\text { KH } \\
\text { (karang hidup) }\end{array}$ & & $68.682 \%$ & $66.34 \%$ & $70.571 \%$ & $205.6 \%$ \\
\hline $\begin{array}{c}\text { KM } \\
\text { (karang mati) }\end{array}$ & $31.318 \%$ & $33.660 \%$ & $29.429 \%$ & $95.01 \%$ \\
\hline $\begin{array}{c}\text { PK } \\
\text { (pecahan karang) }\end{array}$ & $33.660 \%$ & $9.68 \%$ & $90.745 \%$ & $94.977 \%$ & $254.1 \%$ \\
\hline $\begin{array}{c}\text { P } \\
\text { (pasir) }\end{array}$ & $29.429 \%$ & $90.745 \%$ & & $5.023 \%$ & $46.17 \%$ \\
\hline
\end{tabular}

Berdasarkan matriks IK dan ITS yang tersusun diatas, maka didapatkan hasil prosentase yang menunjukkan seberapa besar perbedaan dan kesamaan nilai kerapatan rumput laut berdasarkan tiap substratnya. Prosentase tertinggi pada indeks kesamaan adalah substrat pecahan karang dengan karang hidup, sedangkan prosentase terendah terdapat pada substrat pasir dan karang mati. Berbanding terbalik dengan 
indeks kesamaan, prosentase indeks ketidaksamaan tertinggi terdapat pada substrat karang mati dan pasir, dan terendah adalah substrat karang hidup dengan pecahan karang.

e. Hubungan kerapatan rumput laut dengan substrat dasar berbeda

Hubungan kerapatan rumput laut dengan substrat dasar perairan dapat ditentukan menggunakan uji chi kuadrat. Berdasarkan hasil perhitungan dengan menggunakan analisa data Chi kuadrat di dapatkan $\mathrm{X}^{2}$ hitung dan $X^{2}$ Tabel rumput laut. Pada rumput laut nilai $X^{2}$ hitung sebesar 70,00 dan nilai $X^{2}$ tabel $_{(0,05 ; 24)}$ sebesar 21,026. Maka, jika $\mathrm{X}^{2}$ hitung $>\mathrm{X}^{2}$ tabel maka $\mathrm{H}_{0}$ ditolak dan $\mathrm{H}_{1}$ diterima. Hal tersebut dapat dinyatakan ada hubungan kerapatan rumput laut terhadap substrat dasar di lokasi penelitian.

\section{f. Parameter Perairan}

Pengambilan parameter kualitas air dilakukan pada saat sampling secara langsung (insitu). Adapun parameter yang dilakukan pengukuran sebagai berikut:

Tabel 6. Parameter perairan lokasi penelitian

\begin{tabular}{clccl}
\hline No. & \multicolumn{1}{c}{ Parameter } & Nilai & Kisaran nilai optimum berdasarkan referensi \\
\hline 1. & Kedalaman $(\mathrm{m})$ & $0,15-1,44$ & $5-10$ & (Kordi, 2010) \\
2. & Kecerahan $(\mathrm{cm})$ & $\square$ & & \\
3. & Suhu Air $\left({ }^{\circ} \mathrm{C}\right)$ & 30 & $25-30$ & (Aslan, 1998) \\
4. & Kec. Arus $(\mathrm{m} / \mathrm{s})$ & 0,3 & $0,01-0,03$ & (Trono, 1988) \\
5. & Salinitas $\left({ }^{\circ} / 00\right)$ & 33 & $30-35$ & (Salijo dan Soumokil, 1971) \\
6. & pH & 8 & $7,5-8,4$ & (Darmayasa, 1988) \\
\hline
\end{tabular}

Sumber: Data penelitian 2013

\section{Pembahasan}

a. Jenis rumput laut yang ditemukan di Pantai Bandengan

Berdasarkan Tabel 1, rumput laut pada perairan Pantai Bandengan ditemukan sebanyak sembilan jenis. Rumput laut ini melekat pada substrat-substrat pantai tersebut. Kesembilan jenis tersebut adalah Halimeda macroloba, Halimeda opuntia, Halimeda descoides, Chordoria flagelliformis, Padina crassa, Sargassum yendoi, Sargassum confusum, Sargassum piluliferum, dan Sargassum duplicatum.

Menurut Aslan (1998), kabanyakan spora bersifat planktonis, sehingga sebarannya tersebut dipengaruhi arus. Arus yang lebih kuat akan menggerakkan massa air lebih besar, sehingga dapat mencapai area yang lebih luas. Gerakan air ini akan membawa spora makro alga yang bersifat planktonis tumbuh menyebar di perairan, dengan didukung arus yang stabil maka spora tersebut akan melekat pada substrat yang sesuai untuk tumbuh.

Genus Halimeda paling banyak ditemukan pada pantai ini, namun hanya menempel pada substrat pasir dan pecahan karang, hanya delapan individu yang menempel pada karang mati. Genus Sargassum juga ditemukan banyak tumbuh pada Pantai Bandengan. Sargassum menempel pada hampir seluruh substrat dasar. Sedangkan Chordoria flagelliformis dan Padina crassa adalah jenis rumput laut yang jumlahnya sangat sedikit ditemukan jika dibandingkan jenis lainnya. Menurut Romimohtarto dan Juwana (2001), kehidupan rumput laut pada suatu perairan ditentukan oleh lingkungan dan substrat dasar perairan, dimana substrat tersebut merupakan tempat melekatnya rumput laut/alga.

\section{b. Perhitungan nilai penting rumput laut di Pantai Bandengan}

Berdasarkan pengamatan yang dilakukan di perairan Pantai Bandengan, Jepara didapatkan perbedaan substrat dasar perairan yang dibagi kedalam empat golongan yaitu substrat pasir, pecahan karang, karang mati, dan karang hidup. Pada substrat pasir ditemukan seluruh jenis rumput laut. Rumput laut yang paling banyak ditemukan pada substrat pasir adalah jenis Halimeda macroloba, sedangkan yang paling jarang ditemukan pada substrat pasir adalah jenis Sargassum piluliferum. Secara keseluruhan genus Halimeda sangat mudah ditemukan pada substrat pasir, namun genus Sargassum sangat sedikit ditemukan pada substrat pasir.

Substrat pecahan karang merupakan substrat yang paling banyak ditemukan rumput laut. Kesembilan jenis rumput laut yang ditemukan di Pantai Bandengan hidup pada substrat pecahan karang. Jenis yang paling banyak ditemukan melekat pada substrat ini adalah Halimeda opuntia. Genus Halimeda memang menjadi rumput laut yang paling banyak ditemukan pada substrat pecahan karang. Genus kedua yang juga banyak ditemukan pada substrat pecahan karang adalah Sargassum. Kedua genus ini memang sering ditemukan hidup pada substrat dasar pecahan karang dengan kedalaman yang relatif rendah atau yang masih mendapatkan suplai cahaya matahari. Karena cahaya matahari merupakan faktor penting dalam proses fotosintesis rumput laut tersebut.

Sargassum paling banyak ditemukan pada substrat karang mati. Jenis yang paling banyak ditemukan pada substrat karang mati ini adalah jenis Sargassum confusum dimana penutupan jenis ini sebanyak 7,6 $\mathrm{m}^{2}$. Sedangkan jenis yang paling sedikit ditemukan pada substrat karang mati adalah Halimeda opuntia. Bahkan genus Halimeda lain seperti jenis Halimeda macroloba sudah tidak ditemukan lagi pada substrat karang mati. Jenis lain yang juga tidak ditemukan pada substrat karang mati adalah jenis Chordoria flagelliformis. 
Menurut Anggadiredja (2006), Sargassum sp mampu tumbuh pada substrat batu karang di daerah berombak. Hal ini sesuai dengan hasil pengamatan dengan ditemukannya Sargassum sp yang hidup dan melekatkan diri pada jenis substrat terbanyak pada karang mati dan pecahan karang. Dibandingkan dengan jenis rumput lainnya, Sargassum confusum dan Sargassum duplicatum ditemukan hidup pada substrat karang hidup lebih banyak dari jenis rumput laut lainnya.

Rumput laut sangat sedikit ditemukan pada substrat karang hidup. Pada substrat karang hidup hanya ditemukan tiga jenis rumput laut yaitu jenis Padina crassa, Sargassum confusum, dan Sargassum duplicatum. Prosentase penutupan pada jenis Padina crassa pun hanya 1,06\% dari total penutupan. Sedangkan jenis Sargassum confusum sebesar 1,487\%, dan jenis Sargassum duplicatum sebesar 1,54\% dari total penutupan. Diduga hal ini terjadi karena pada substrat karang hidup masih terdapat lendir pada permukaannya sehingga mempersulit penempelan thallus rumput laut tersebut.

Berdasarkan pengamatan di Pantai Bandengan, didapatkan hasil nilai kerapatan rumput laut terhadap substrat dan nilai KR, PR, FR, serta NP-nya. Nilai tersebut dapat dilihat dalam Tabel 1. Jumlah kerapatan individu terbanyak adalah Halimeda opuntia, yaitu sebanyak 103 individu atau 18,19\% untuk kerapatan relatifnya. Halimeda lainnya juga termasuk mempunyai nilai kerapatan tinggi, seperti Halimeda macroloba 17,31\% atau sebanyak 98 individu dan Halimeda descoides 14,84\% atau 84 rumput laut. Padina crassa mempunyai nilai kerapatan relatif tinggi yaitu $13,42 \%$ dengan jumlah individu 76 . Hal ini dikarenakan jenis tersebut sangat cocok tumbuh pada kedalaman dangkal yang masih mendapatkan cahaya matahari dan substrat dasar pecahan karang serta pasir. Menurut Nontji (1993), tumbuhan air akan hidup baik pada kedalaman dimana sinar matahari masih dapat menembus perairan. Sedangkan pada jenis Chordoria flagelliformis hanya mempunyai nilai kerapatan relatif 7,95\% atau sebanyak 84 rumput laut. Sama seperti Sargassum yang kerapatannya rendah.

Penutupan terbanyak berdasarkan Tabel 4 adalah jenis rumput laut Sargassum duplicatum yaitu 15 $\mathrm{m}^{2}$ atau sekitar $15,9 \%$. Genus Sargassum lain seperti Sargassum confusum, Sargassum duplicatum, dan Sargassum yendoi juga mempunyai nilai penutupan tinggi yaitu antara $9-14,1 \mathrm{~m}^{2}$. Hal ini dikarenakan jenis Sargassum sp sangat cocok tumbuh dan berkembang pada perairan ini, dimana parameter perairan sangat mendukung kehidupan Sargassum yang membutuhkan perairan dangkal serta substrat dasar karang mati dan pecahan karang. Pernyataan ini didukung oleh Junaidi (2009), Sargassum sp hidup dengan baik ditepi laut yang dangkal. Umumnya menempel pada batu karang dan karang hidup pada pantai bersuhu rendah.

Berbeda jenis rumput laut Halimeda sp yang jarang ditemukan di substrat karang mati bahkan tidak ada yang ditemukan di karang hidup. Jenis Halimeda sp cenderung ditemukan pada substrat pecahan karang dan pasir. Substrat yang seperti ini banyak ditemukan pada meter-meter awal yang masih mendapatkan sinar matahari secara intensif. Halimeda opuntia dan Halimeda descoides merupakan jenis rumput laut Halimeda sp yang ditemukan di substrat karang mati, namun penutupannya sangat sedikit yaitu $0,40 \mathrm{~m}^{2}$ dan $0,45 \mathrm{~m}^{2}$. Berbeda dengan dua jenis rumput laut tersebut, Halimeda macroloba tidak ditemukan pada substrat dasar karang mati.

Kondisi yang hampir sama juga ditemukan pada jenis rumput laut Chordoria flagelliformis dimana jenis ini banyak dijumpai pada substrat dasar berpasir dan pecahan karang. Jumlah yang ditemukan pada rumput laut jenis ini juga tergolong sedikit yaitu 45 rumput laut dengan penutupan yang bernilai rendah dibanding jenis lain sekitar $4,90 \mathrm{~m}^{2}$. Hal ini diduga karena jenis ini sedang berada pada awal pertumbuhan sehingga persebaran dan pertumbuhannya belum maksimal.

Jenis rumput laut Padina crassa ditemukan sebanyak 76 individu dan tersebar di keempat jenis substrat dasar dan mempunyai total penutupan $7,55 \mathrm{~m}^{2}$, dimana jenis ini ditemukan pada seluruh jenis substrat dasar perairan. Nilai penutupan Padina crassa terhadap substrat dasar karang hidup adalah $1 \mathrm{~m}^{2}$, sedangkan pada karang mati sebanyak $1,40 \mathrm{~m}^{2}$, pada pecahan karang ditemukkan $2,80 \mathrm{~m}^{2}$, dan terakhir pada substrat dasar berpasir sebanyak $2,35 \mathrm{~m}^{2}$. Hal ini seperti yang dinyatakan oleh Kadi (1996), Padina sp merupakan alga dari kelas Phaeophyta yang banyak dijumpai di seluruh pantai Indonesia terutama pada rataan terumbu karang hingga kedalaman $200 \mathrm{~m}$.

Padina crassa merupakan salah satu jenis rumput laut yang mempunyai kemampuan menempel pada batu di rataan terumbu maupun pasir, oleh sebab itu Padina crassa adalah salah satu jenis rumput laut yang mampu tumbuh baik pada hampir di seluruh substrat dasar, selain itu kesesuaian substrat juga berpengaruh pada kerapatan rumput laut, seperti yang diungkapkan Soegiarto (1978), bahwa kesesuaian substrat dasar sangat berpengaruh pada kerapatan rumput laut.

Walaupun Padina crassa ditemukan di seluruh substrat dasar, namun jumlahnya tidak sebanyak genus Halimeda, dikarenakan jenis ini memiliki kemampuan yang lemah untuk melekatkan diri pada substrat, seperti yang dikemukakan Romimohtarto dan Juwana (2001), yaitu spesies ini hidupnya melekat pada substrat karang mati atau pasir, spesies ini memiliki akar yang serupa rambut tebal sehingga perlekatannya lebih lemah dibandingkan makroalga jenis lainnya.

\section{c. Nilai Indeks Kesamaan dan Indeks Ketidaksamaan pada rumput laut}

Dari hasil matriks Indeks Kesamaan pada substrat karang hidup dan karang mati didapatkan nilai $31,918 \%$ dan Indeks Ketidaksamaan sebesar $68,17 \%$ yang berarti vegetasi rumput laut pada substrat ini 
cukup berbeda karena nilai Indeks Ketidaksamaannya lebih tinggi. Pada substrat karang hidup terhadap pecahan karang didapatkan nilai Indeks Ketidaksamaan 66,34\% yang berarti lebih besar dari Indeks Kesamaan, hal ini menunjukkan bahwa vegetasinya juga cukup berbeda. Walaupun jaraknya berdekatan namun pada substrat pecahan karang dan karang mati mendapatkan nilai Indeks Ketidaksamaan jauh lebih tinggi yaitu 90,744\% dengan nilai Indeks Kesamaan 9.255\% yang berarti kondisi vegetasi perairan Pantai Bandengan tersebut berbeda. Pada substrat pasir dan karang mati juga terdapat selisih nilai yang signifikan yaitu Indeks Ketidaksamaan 94,976\% sedangkan Indeks Kesamaan yaitu 5,023\%. Nilai ini menunjukkan bahwa dengan lebih tingginya nilai Indeks Ketidaksamaan maka rumput laut pada substrat dasar yang berbeda di perairan Pantai Bandengan memiliki vegetasi yang berbeda-beda pula

\section{d. Hubungan kerapatan rumput laut dengan substrat dasar berbeda}

Berdasarkan hasil perhitungan dengan menggunakan analisa data Chi Kuadrat di dapatkan $\mathrm{X}^{2}$ hitung dan $X^{2}$ Tabel rumput laut. Pada rumput laut nilai $X^{2}$ hitung sebesar 72,00 dan nilai $X^{2}$ Tabel sebesar 21,026. Berdasarkan kaidah pengambilan keputusan probabilitas, jika $\mathrm{X}^{2}$ hitung $\geq \mathrm{X}^{2}$ Tabel maka $\mathrm{H}_{0}$ ditolak dan $\mathrm{H}_{1}$ diterima. Hal tersebut dapat dinyatakan ada hubungan kerapatan rumput laut terhadap substrat dasar di lokasi penelitian karena $\mathrm{X}^{2}$ hitung $\geq \mathrm{X}^{2}$ Tabel yang menyatakan terima $\mathrm{H}_{1}$ tolak $\mathrm{H}_{0}$.

Data yang digunakan dalam pengujian chi kuadrat adalah hasil perhitungan Indeks Kesamaan, dimana indeks ini merupakan total perhitungan seluruh nilai penting. Nilai penting merupakan penjumlahan dari nilai kerapatan relatif (KR), frekuensi relatif (FR), dan penutupan relatif (PR). Maka penggunaan data Indeks Kesamaan dalam pengujian chi kuadrat dinilai sudah cukup mewakili keseluruhan perhitungan yang dibutuhkan pada penelitian rumput laut ini.

\section{e. Parameter Perairan}

Kecerahan pada perairan Pantai Bandengan ini tidak terhingga, nilai ini termasuk tinggi. Rumput laut sangat membutuhkan sinar matahari yang cukup untuk melakukan fotosintesis di perairan. Adapun kekeruhan pada perairan akan menyebabkan penetrasi cahaya yang masuk akan berkurang. Menurut Perkins (1974), selain mengurangi penetrasi cahaya yang masuk ke parairan, kekeruhan juga menyebabkan pengendapan yang cukup besar dan akan membentuk lumpur.

Rumput laut ditemukan pada kedalaman antara $15-144 \mathrm{~cm}$, hal ini sangat baik karena menurut Kordi (2010), rumput laut membutuhkan tingkat kedalaman yang baik bagi pertumbuhannya. Untuk Rhodophyta, kedalamannya mulai dari garis pasang surut terendah sampai sekitar 5 meter, sedangkan Chlorophyta dapat ditemukan hingga kedalaman 10 meter atau lebih di daerah yang mendapat penyinaran cukup. Selain itu juga Phaeophyta seperti Sargassum sp hidup di daerah rataan terumbu karang sampai cahaya masih dapat masuk ke perairan.

Suhu merupakan faktor yang sangat penting dalam pertumbuhan rumput laut. Menurut Dawes (1981), dalam pertumbuhannya, rumput laut membutuhkan suhu sekitar $27^{\circ} \mathrm{C}-30^{\circ} \mathrm{C}$, untuk batas ambang suhu pertumbuhan alga hijau, coklat dan merah adalah $34,5^{\circ} \mathrm{C}$. Suhu mempunyai peranan yang sangat penting bagi kehidupan dan pertumbuhan rumput laut. Suhu air dapat berpengaruh pada beberapa fungsi fisiologis rumput laut seperti fotosintesis, respirasi, metabolisme, pertumbuhan, dan reproduksi. Hasil pengukuran suhu pada penelitian ini adalah $30^{\circ} \mathrm{C}$ yang berarti suhu perairan merupakan suhu yang bagus untuk pertumbuhan rumput laut di perairan ini.

Kecepatan arus pada perairan saat dilakukan sampling adalah $0,3 \mathrm{~m} / \mathrm{s}$. Aslan (1998) menyatakan bahwa arus merupakan faktor pembatas dalam penyebaran spora, pelekatan, dan pertumbuhan rumput laut, hal ini dikarenakan zat hara yang ada di perairan dibawa oleh arus, sehingga zat hara di dalam perairan dapat tersebar. Selain itu gerakan air mempengaruhi melekatnya spora pada substratnya. Kisaran nilai arus untuk pertumbuhan rumput laut adalah $0,01-0,33 \mathrm{~m} / \mathrm{s}$.

Salinitas merupakan kandungan garam dalam suatu perairan. Kesuburan rumput laut dipengaruhi oleh kadar garam atau salinitas perairan tersebut (Aslan, 1998). Berdasarkan hasil pengukuran, nilai salinitas pada perairan tersebut adalah 33 ppt. Menurut Anggadiredja (2006), faktor yang sangat berpengaruh pada pertumbuhan rumput laut yaitu cukup arus dan salinitas yang stabil berkisar antara 28-42 ppt. Maka nilai salinitas yang sudah diukur termasuk masih batas aman toleransi rumput laut untuk tumbuh.

Nilai $\mathrm{pH}$ suatu perairan mempunyai pengaruh yang besar terhadap organisme perairan sehingga seringkali dijadikan petunjuk untuk menyatakan baik buruknya suatu perairan (Odum, 1971). Hasil pengukuran lapangan menyatakan bahwa nilai kandungan $\mathrm{pH}$ pada perairan adalah 8 . Berdasarkan referensi Trono (1988), bahwa perairan laut umumnya mempunyai $\mathrm{pH}$ berkisar antara $7,5-8,4$, sedangkan kondisi layak bagi kehidupan rumput laut antara 6,8-9,6. Hal ini sesuai dengan pengukuran lapangan, sehingga kondisi perairan memang cocok untuk kehidupan biota.

\section{KESIMPULAN}

Kesimpulan yang dapat diambil dari penelitian ini adalah Kerapatan tertinggi terdapat pada spesies Halimeda opuntia yaitu 103 individu/ $300 \mathrm{~m}^{2}$ sedangkan kerapatan terendah adalah jenis Sargassum piluliferum yaitu 30 individu/ $300 \mathrm{~m}^{2}$. Penutupan relatif tertinggi adalah Sargassum duplicatum yaitu 15,9\% dan terendah adalah Chordoria flagelliformis sebesar 5,2\%. Berdasarkan nilai uji chi kuadrat $\mathrm{X}^{2}$ hitung 
sebesar 72,00; dan $X^{2}$ tabel $_{(0,05 ; 24)}$ sebesar 21,026 maka $X^{2}$ hitung $>X^{2}$ tabel, jadi terdapat hubungan nyata antara kerapatan rumput laut dengan substrat dasar perairan.

\section{UCAPAN TERIMAKASIH}

Penulis mengucapkan terimakasih kepada Ir. Ruswahyuni, M.Sc dan Dra. Niniek Widyorini, MS atas bimbingan dan arahannya dalam penyusunan jurnal ini.

\section{DAFTAR PUSTAKA}

Anggadiredja, T. 2006. Rumput Laut. Penebar Swadaya. Jakarta.

Anggadiredja, T. A. Zatnika, H. Purwoto, dan Istini. 2009. Rumput Laut. Penebar Swadaya. Jakarta. 147. Dalam: Yaqin, Khusnul, Burhanuddin, Iqbal, Samd, Wasir. 2011. Biodiversity of Seaweed and Their Metal Contents from Littoral Zone of South Sulawesi Waters [Research Report]. Jurusan Kelautan FPIK Universitas Hasanuddin. Makassar.

Aslan, M. 1998. Rumput Laut. Penerbit Kanisius. Yogyakarta.

Darmayasa, I.G.P. 1988. Studi Perbandingan Laju Pertumbuhan Alga Merah Euchema spinosum (L) pada Kedalaman yang Berbeda di Perairan Pantai Geger, Nusa Dua, Bali, Dalam: Karya Ilmiah Fakultas Perikanan IPB Bogor.

Dawes, C.J. 1981. Marine Botany. John Willeya and Sons, Inc. New York. 628pp.

Junaidi, W. 2009. Ganggang Coklat Kelas Phaeophyta. http://www.wjunaidi.com /2009/10/26/ganggangcoklat-kelasphaeophyta.php (12 November 2012).

Kadi, A. 1996. Pengenalan Jenis-Jenis Rumput Laut Indonesia. Pusat Penelitian dan Pengembangan Oseanologi LIPI. Jakarta.

Kordi, K. 2010. Budidaya Biota Akuatik Untuk Pangan, Kosmetik, dan Obat-obatan. Penerbit ANDI. Yogyakarta.

Nontji, A. 1993. Laut Nusantara. Djambatan. Jakarta.

Odum, E.P. 1971. Fundamental of Ecology. W.B. Sounders Company. Philadelphia, London, Toronto. 557pp.

Perkins, J. 1974. The Biology, Revised Edition. Reston Publishing Company Inc. Reston. Virginia. USA.

Romimohrato, K dan S. Juwana. 2001. Biologi Laut, Ilmu Pengatahuan tentang Biologi Laut. Djambatan. Jakarta.

Salidjo, B. Dan Soumokil. 1971. Oseanografi Umum dan Korelasi Oseanografi Indonesia (LON-LIPI). Jakarta.

Sandjaya. 2006. Metode Penelitian Ilmiah. PT. Gramedia. Jakarata

Soegiarto, A., W.S. Atmadja, Sulistyo, dan Mubarak. 1978. Rumput Laut (Algae): Manfaat, Potensi, dan Usaha Budidayanya, LON-LIPI. Jakarta.

Sudjana. 2005. Metode Statistika. Tarsito. Bandung.

Trono. J.R. 1988. Euchema Farming in The Philipines, UP. NATURAL Science. Research Center. Quizon City. 